\title{
The Initial Growth of Passion Fruit Plant Irrigated With Saline Water and the Application of Biostimulants
}

\author{
Jolinda M. de Sá ${ }^{1}$, Erllan T. C. Leitão ${ }^{2}$, Camile D. L. Gomes ${ }^{1}$, Marília H. B. S. Rodrigues ${ }^{1}$, Valéria F. de O. Sousa ${ }^{1}$, \\ Gisele L. dos Santos ${ }^{1}$, Raul A. P. de Melo ${ }^{3}$, Antônio F. de Mendonça Júnior ${ }^{4}$, Jhonatan S. P. de Lacerda ${ }^{3}$ \\ \& Adriana da S. Santos ${ }^{1}$ \\ ${ }^{1}$ Academic Unit of Tropical Horticulture, Federal University of Campina Grande, Pombal, PB, Brazil \\ ${ }^{2}$ Academic Unit of Soil and Water Management, Semiarid Federal Rural University, Mossoró, RN, Brazil \\ ${ }^{3}$ Academic Unit of Agricultural Science, Federal University of Campina Grande, Pombal, PB, Brazil \\ ${ }^{4}$ Academic Unit of Agronomy, Rural Federal University of Pernambuco, Recife, PE, Brazil \\ Correspondence: Valéria F. de O. Sousa, Academic Unit of Tropical Horticulture, Federal University of Pombal, \\ Paraíba, Brazil. Tel: 55-083-999-431-191. E-mail: valeriafernandesbds@gmail.com
}

Received: May 25, 2018

doi:10.5539/jas.v10n9p357
Accepted: June 28, $2018 \quad$ Online Published: August 15, 2018

URL: https://doi.org/10.5539/jas.v10n9p357

\begin{abstract}
The salinity is one of the stresses that more limits the income of the agricultural cultures, mainly in areas semiarid as the Northeast, though, it is known that the biostimulants are substances capable to alter the metabolism of the plant and to favor development under adverse conditions of stresses. In this context, it was aimed at with this work to evaluate the initial growth of the passion fruit plant irrigated with saline water and the application of biostimulants. The experiment was conducted at the Federal University of Campina Grande, campus Pombal, in factorial outline $5 \times 3$, corresponding to five salinity levels $(\mathrm{S} 1=0.3$; $\mathrm{S} 2=2.3$; $\mathrm{S} 3=3.3$; $\mathrm{S} 4$ $=4.3$ and $\left.\mathrm{S} 5=5.3 \mathrm{dS} \mathrm{m}^{-1}\right)$ and two biostimulants $(\mathrm{B} 1=$ Acadian and $\mathrm{B} 2=$ Crop Set $)$ and treatment testifies (without an application of biostimulant). The dose used for each product was $4 \mathrm{ml} \mathrm{L}^{-1}$ of Acadian and $3 \mathrm{ml} \mathrm{L}^{-1}$ of Crop Set. It was used seeds of the passion fruit of the variety BRS-giant, sowed in containers of black polypropylene of $400 \mathrm{ml}$, containing sand and substrate Carolina Soil, in the proportion 1:1. For the 32 days after the sowing was determined the height, the root length, the fresh and dry mass (aerial, root and total) of plants, the biomass production and the index of tolerance the salinity. The data were submitted to the variance analysis of the test $\mathrm{F}$ at the level of $5 \%$ of probability, and when significant, the averages were submitted to the test Tukey for both factors, saline levels and biostimulants. The use of vegetable biostimulants increases the initial growth of the yellow passion fruit plant. The salinity in the irrigation water attacks the growth, however, I use of the biostimulant Crop Set lessens the harmful effect in passion fruit seedlings.
\end{abstract}

Keywords: Passiflora edulis Sim, vegetable regulators, salinity

\section{Introduction}

Belonging to the family Passifloraceae the yellow passion fruit plant (Passiflora edulis Sims. f. flavicarpa Deg.) it represents one of the most fruitful of larger socioeconomic prominence in Brazil, due to the quality of their fruits, of the largest industrial income and still for the generation of jobs during cultivation (Zacharias et al., 2016).

Among the producing areas the Northeast is responsible for more of the half of the national production, however, areas semiarid as it is the case of the Northeast, they are dependent on the irrigation use, tends to view the precipitation irregular rainfall during the year. The water resources available in those areas, are usually considered of inferior quality, for they possess concentrations of salts, that can in excess to commit the soil for salinity and the development of the cultures (Nascimento et al., 2017).

The salinity induces several answers morphologic, physiologic and biochemistries in the plants, among the ones which: alterations of the osmotic potential, ionic toxicity and unbalance of the absorption of the nutrients, being, therefore, the growth of the plants delayed (Freire et al., 2014; Bezerra et al., 2016). 
The biostimulants for them are substances, natural or synthetic capable to favor the expression of the genetic potential of the plants by alterations in the vital and structural processes, promoting the hormonal balance (Santos et al., 2013).

According to Oliveira et al. (2016), the biostimulants user can be an alternative to aid the plants in the overcoming of abiotic stresses, once they act as increment hormone and also nutritional. Ferraz et al. (2014), they verified to obtain the better development of plantules of Passiflora edulis in a smaller time through the use of biostimulant, though, without stress presence, what turns necessary researches to treat on that aspect, mainly being treated of a fruitful of great importance.

With base in these statements, the use of measures capable to soften or acclimatizing the plant the such stress types become decisive to the incomes of the produce section, being the objective of this work to evaluate the initial growth of the passion fruit plant irrigated with saline water under application of biostimulants.

\section{Materials and Methods}

The experiment was conducted in the house of the vegetation of the Center of Sciences and Technology Agrofood of the Federal University of Campina Grande, campus of Pombal, Paraíba. According to the climatic classification of Köppen, adapted Brazil (Coelho \& Soncin, 1982), the climate is of the type BSh, representing climate hot and dry, semiarid, with medium precipitation from 700 to $900 \mathrm{~mm}$ year ${ }^{-1}$, annual medium temperature of $26.1^{\circ} \mathrm{C}$ and annual medium evaporation from 1000 to $1100 \mathrm{~mm}$ (Francisco \& Santos, 2017).

The experiment was conducted in randomized blocks in factorial outline $5 \times 3$, corresponding to five salinity levels: $\mathrm{S} 1=0.3 ; \mathrm{S} 2=2.3 ; \mathrm{S} 3=3.3 ; \mathrm{S} 4=4.3$ and $5.3 \mathrm{dS} \mathrm{m}^{-1}$, the other factor was composed by two biostimulants: B1 = Acadian and B2 = Crop Set; and treatment testify (without biostimulant application), with four repetitions, equivalent to 60 experimental portions.

Seeds of fruits of passion fruit of the variety BRS-giant were used, in complete maturation stadium and properly healthy. The fruits were obtained in free markets in the city of Pombal, Paraíba. For the removal of the aril of the seeds the mechanical method was used to use of a blender, whose helixes were stamped with adhesive ribbon to avoid damages to the seeds and washed in running water with the aid of a mesh sieve dies. After the extraction, the seeds were put to dry on two leaves of paper towel in a room temperature of approximately $25{ }^{\circ} \mathrm{C}$ for five days for then be used.

The seeds were sowed in containers of black polypropylene of $400 \mathrm{ml}$, containing sand and substrate Carolina Soil, in the proportion 1:1, with two seeds for container. The emergency was verified in the seven days after the sowing and the rough-hewing, it was accomplished to the 10 days after sowing (DAS), being left a plentiful by the container.

The saline solutions were prepared with an increment of chloride of sodium to the water of the system of local provisioning (CAGEPA) with base in the equation of Rhoades, Kandiah, and Mashaliet (2000), checking the electric conductivity with the aid of a portable conductivity meter, being stocked in closed plastic containers with a capacity for 5 liters of the solution. The irrigation with saline water was made daily, leaving the soil in field capacity. $\mathrm{Q}=(\mathrm{CEw} \times 640)$, in that: $\mathrm{Q}=$ Amount of $\mathrm{NaCl}\left(\mathrm{mg} \mathrm{L}^{-1}\right)$; $\mathrm{CEw}=$ Represents the wanted value of the electric conductivity of the water $\left(\mathrm{dS} \mathrm{m}^{-1}\right)$.

The application of the products was accomplished in the 8 days after the emergency (DAE), when the seedlings presented at least two true leaves, to $16 \mathrm{DAE}$ and $24 \mathrm{DAE}$. The dose used for each product was $4 \mathrm{ml} \mathrm{L}^{-1}$ of Acadian and $3 \mathrm{ml} \mathrm{L}^{-1}$ of Crop Set, being this application accomplished through foliating with the aid of a sprayer.

For the 32 days after the sowing was determined the following growth variables:

Height of the plant: it was measured between the lap of the plant and the highest branch, through a graduate tape measure in centimeters.

Root length: checked with the aid of millimeter ruler.

Fresh and dry mass of plants (aerial, root and total): the plants were separate partly aerial and root and heavy in the analytical scale of precision for obtaining of the fresh mass, later they were put in paper bags, kraft, previously identified and dried in greenhouse regulated $65{ }^{\circ} \mathrm{C}$, until reaching a constant weight (48 hours) and, elapsed that period, the samples were heavy in analytical scale accurately about $0,001 \mathrm{~g}$. The dries total mass was certain for the sum of the mass dries of the aerial part and mass dries of the root, being all the expressed results in grams. 
Biomass production $(P B)$ : it was certainly for the methodology described by Emon et al. (2015), expressed by the formula $\mathrm{PB}=(\mathrm{MST} / \mathrm{MFT}) \times 100$, in that MST $=$ mass of the matter dries of the plant and MFT $=$ mass of the fresh matter of the plant.

Index of tolerance to the salinity: it was accomplished being used the growth data, according to methodology of Araújo et al. (2016) for the following formula: ITS (\%) = (Production of MST in the saline treatment)/ (Production of MST in the treatment controls) $\times 100$.

The data were submitted to the variance analysis of the test $\mathrm{F}$ at the level of $5 \%$ of probability, and when significant, the averages were submitted to the test Tukey for both factors, saline levels and biostimulants, using the Sisvar software version 5.6 (Ferreira, 2014).

\section{Results and Discussion}

The initial growth of the yellow passion fruit plant was influenced significantly $(p>1)$ for the saline levels in the irrigation water and biostimulant application in all of the phenological parameters appraised, demonstrating that the factors salinity in the irrigation water and biostimulant application acts in a united way (Table 1).

The height of the seedlings of yellow passion fruit plant (Table 2) was influenced so much by the saline levels in the irrigation water as for the application of the biostimulants, it was observed that were verified in the absence of the application of the biostimulant to the smallest averages, however, the use of the same ones increased the growth in height, however it didn't lessen the noxious effect of the saline stress. In agreement with Oliveira et al. (2017) the biostimulant use favors the growth and biomass production, but it doesn't lessen the effect of the saline stress and when used in high doses potentiate the effect of the salinity.

In the root length, it verified reductions in function of the increment of salts in the water, however, no significant, with the use of the biostimulant Crop Set (B2), so on this biostimulant favored the best development of the root system up to $4.3 \mathrm{dS} \mathrm{m}^{-1}$ (Table 2). Behavior similar to the observed in the height of the plants, which the absence of the application of the biostimulant caused smaller growth. The application of vegetable regulators (biostimulants) during the initial stadiums of development of the plant, promotes root development, improves the nutritional absorption and provides stabilization in stress conditions (Silva, Bolfarini, Rodrigues, Ono, \& Rodrigues, 2014).

In relation to fresh mass of the aerial part, the treatment without application of biostimulant didn't suffer significant influence with the increase of the electric conductivity of the irrigation water, still presenting the smallest values, while the biostimulants use through foliating provided reduction of $33.33 \%$ and $20.68 \%$ when was used the bioestimulante Acadian ${ }^{\circledR}$ (B1) and B2, respectively, when compared to the smaller (S1) and larger (S5) saline level (Table 2).

For fresh mass of the root system of the passion fruit plant seedlings, was verified that the salinity interfered significantly, with unitary decreases of $15 \%$ (without biostimulant), $12.36 \%$ (B1) and $23.90 \%$ (B2) with an increment of the saline waters. However, the biostimulant B2 was statistically superior in relation to the other treatments, B1 and without application of biostimulant (Table 2).

Oliveira et al. (2015) evaluate the interaction between salinity and biostimulant in the initial growth of pinhão-tame, they verified that the biostimulant Stimulate ${ }^{\circledR} 10 \mathrm{X}$ didn’t inhibit the harmful effect of the salinity of the irrigation water on this species. Studies regarding the biostimulant Acadian and Crop Set in conditions of salinity stress were not found in the literature. In the study accomplished by Souza Neta et al. (2018), it is ended, that the biostimulant Stimulate is not efficient to reduce the effect of the salinity on the growth and production of maxixeiro, but it increases the production of fruits, independent of the salinity.

However, Batista-Sánchez et al. (2017) observed that the tenor of fresh mass in basil seedlings decreased with the increase of the salinity, however, the use of the bioregulator FitoMas- $® 囚$ in the concentrations 0.5 and $1 \mathrm{ml}$ $\mathrm{L}^{-1}$ lessens the effect of the moderate saline stress the seriousness. According to these same authors that behavior happens due, this bioregulator to favor the best development of the root system of the plant, soon depending on the type of biostimulant and the used concentration, as well as the application form is possible reduction the caused harmful effects the plants when submitted to stress conditions.

Crop Set is a vegetable stimulant composed of extracts of Agave (Yucca schidigera) and mineral micronutrients, with action similar to the cytokinins, besides, it possesses the following micronutrients: $1 \%$ of copper, $4,69 \%$ of sulfur, $2.5 \%$ of iron and $3 \%$ of manganese (Ramos et al., 2015) while, Acadian is extract of sea algae of the species Ascophyllum nodosum, which synthesizes vegetable hormones, as for instance, auxins, gibberellins, cytokinins, abscisic acid, and they possess carbohydrates and important concentrations of nutrients as $\mathrm{N}, \mathrm{P}, \mathrm{K}, \mathrm{Ca}$, $\mathrm{Mg}, \mathrm{S}, \mathrm{B}, \mathrm{Fe}, \mathrm{Mn}, \mathrm{Cu}$ and $\mathrm{Zn}$ (Arrais et al., 2016). 
Table 1. Summary of the analysis of variance of the height (HEIG), root length (RL), fresh shoot mass (FSM), root (FRP), total (FMAP), mass dries aerial part (MRF), root (TFM) and total (TDM), percentile of biomass (PB) and index of tolerance to the salinity (IT) in the initial growth of yellow passion fruit plant submitted to saline levels of the irrigation water and application of biostimulants. UFCG, Pombal, 2018

\begin{tabular}{|c|c|c|c|c|c|c|c|c|c|c|c|}
\hline \multirow{2}{*}{ SV } & \multirow{2}{*}{ GL } & \multicolumn{10}{|c|}{ Mean Square } \\
\hline & & HEIG & $\mathrm{RL}$ & FSM & FRP & FMAP & MRF & TFM & TDM & $\mathrm{PB}$ & IT \\
\hline$S$ & 4 & $2.39 \mathrm{~ns}$ & $27.62 * *$ & $0.01 * *$ & $0.40^{* *}$ & $0.71 * *$ & $0.01 * *$ & $0.05 * *$ & $0.04 * *$ & $275.80 * *$ & $5145.09^{* *}$ \\
\hline B & 2 & $60.47^{* *}$ & $59.55^{* *}$ & $0.63 * *$ & $3.05^{* *}$ & $5.96^{* *}$ & $0.01 * *$ & $0.009^{* *}$ & $0.03^{* *}$ & $2697.58^{* *}$ & $553.12 * *$ \\
\hline $\mathrm{S} \times \mathrm{B}$ & 8 & $3.77 * *$ & $20.44 * *$ & $0.005^{* *}$ & $0.14 * *$ & $0.11^{* *}$ & $0.0009 * *$ & $0.05 * *$ & $0.01 * *$ & $555.19^{* *}$ & $127.32 * *$ \\
\hline Block & 3 & $3.47 *$ & $0.14 * *$ & $0.005 * *$ & $0.001 \mathrm{~ns}$ & $0.01^{* *}$ & $0.002 * *$ & $0.001 * *$ & $0.006 * *$ & $1.27 \mathrm{~ns}$ & $12.12 \mathrm{~ns}$ \\
\hline Residue & 42 & 0.99 & 1.46 & 0.001 & 0.001 & 0.002 & 0.0002 & 0.0003 & 0.002 & 6.78 & 9.40 \\
\hline Total & 59 & & & & & & & & & & \\
\hline CV (\%) & & 11.77 & 10.22 & 9.94 & 6.99 & 5.16 & 17.42 & 13.87 & 22.37 & 9.90 & 4.25 \\
\hline Mean & & 8.45 & 11.85 & 0.35 & 0.55 & 0.93 & 0.083 & 0.12 & 0.20 & 26.31 & 72.18 \\
\hline
\end{tabular}

Note. ${ }^{\text {ns }}$ no significant, ${ }^{* *}$ significant at $1 \%$ of probability; $*$ significant at $5 \%$ of probability for the test $\mathrm{F}$; CV: variation coefficient.

Table 2. Height of the plant (HEIG), root length (RL), fresh shoot mass (FSM) and fresh root pasta (FRP) in the initial growth of yellow passion fruit plant under saline levels and without and with application of biostimulants. UFCG, Pombal, 2018

\begin{tabular}{|c|c|c|c|c|c|c|c|c|c|c|c|c|}
\hline & \multicolumn{3}{|c|}{ HEIG } & \multicolumn{3}{|c|}{$\mathrm{RL}$} & \multicolumn{3}{|c|}{ FSM } & \multicolumn{3}{|c|}{ FRP } \\
\hline & SEM & B1 & B2 & SEM & B1 & B2 & SEM & B1 & B2 & SEM & B1 & B2 \\
\hline S1 & $5.75 \mathrm{Bb}$ & $10.25 \mathrm{Aa}$ & $11.50 \mathrm{Aa}$ & $9.50 \mathrm{Bb}$ & $15.37 \mathrm{Aa}$ & $15.25 \mathrm{Aa}$ & $0.15 \mathrm{Ac}$ & $0.45 \mathrm{Ab}$ & $0.58 \mathrm{Aa}$ & $0.15 \mathrm{Ac}$ & $0.91 \mathrm{Ab}$ & $1.51 \mathrm{Aa}$ \\
\hline $\mathrm{S} 2$ & 7.97Aa & $8.67 \mathrm{Aba}$ & $9.25 \mathrm{Ba}$ & $11.50 \mathrm{ABb}$ & $13.75 \mathrm{ABa}$ & $14.66 \mathrm{Aa}$ & $0.17 \mathrm{Ac}$ & $0.35 \mathrm{BCb}$ & 0.56 Aca & $0.22 \mathrm{Ac}$ & $0.54 \mathrm{Cb}$ & $0.97 \mathrm{Ba}$ \\
\hline S3 & $6.75 \mathrm{ABb}$ & $7.62 \mathrm{Bb}$ & $10.16 \mathrm{ABa}$ & $12.32 \mathrm{Aab}$ & $10.33 \mathrm{CDb}$ & $13.25 \mathrm{Aa}$ & $0.19 \mathrm{Ac}$ & $0.35 \mathrm{BCb}$ & $0.52 \mathrm{ABCa}$ & $0.18 \mathrm{Ac}$ & $0.37 \mathrm{Cb}$ & $0.97 \mathrm{Ba}$ \\
\hline $\mathrm{S} 4$ & $6.00 \mathrm{ABb}$ & $8.87 \mathrm{Aba}$ & $9.72 \mathrm{ABa}$ & $5.75 \mathrm{Cc}$ & $11.5 \mathrm{BCb}$ & $14.00 \mathrm{Aa}$ & $0.14 \mathrm{Ac}$ & $0.41 \mathrm{ABb}$ & $0.50 \mathrm{BCa}$ & $0.21 \mathrm{Ac}$ & $0.49 \mathrm{BCb}$ & $0.63 \mathrm{Ca}$ \\
\hline S5 & $6.37 \mathrm{ABb}$ & $8.62 \mathrm{Aba}$ & $9.33 \mathrm{Ba}$ & $11.25 \mathrm{ABa}$ & $9.00 \mathrm{Db}$ & $10.37 \mathrm{Bab}$ & $0.17 \mathrm{Ac}$ & $0.30 \mathrm{Cb}$ & $0.46 \mathrm{Ca}$ & $0.06 \mathrm{Bc}$ & $0.46 \mathrm{Cb}$ & $0.66 \mathrm{Ca}$ \\
\hline
\end{tabular}

Note. Saline levels (S1: 0.3; S2: 2.3; S3: 3.3; S4: 4.3 and S5: $5.3 \mathrm{dS} \mathrm{m}^{-1}$ ); Biostimulants (SEM: without biostimulant application; B1: Acadian and B2: Crop Set).

* Following averages for the same small letter in the line and capital letter in the column don't differ statistically amongst themselves for the test of Tukey to $5 \%$ of probability.

In the mass dries of the aerial part (FSM) and root (FRP), it was verified that MSPA in the treatment without use of the biostimulant and with use of the product Acadian decreased 62.5\% and 57\% strongly, respectively, in the largest and smaller saline level, if compared with the seedlings that were cultivated with the use of the biostimulant B2, which demonstrated decrease of $18 \%$, in this same interval of the saline levels (Table 3). MSR of the plants in a similar way was inversely proportional to the increment of $\mathrm{NaCl}$ in the water in the absent treatment of vegetable regulator, reducing 95\% among adult and smaller conductivity level, however the biostimulant Acadian and Crop Set increased MSR up to $2.3 \mathrm{dS} \mathrm{m}^{-1}$ (S2), refusing in the other concentrations.

The data of fresh mass (FMAP) and total drought (MRF), they are in the Table 3. It is observed that these data presented significant effect on the interaction between the salinity and the types of biostimulant. In TFM decrease of 56.3, was verified 44.5 and $46.4 \%$ between adult's interval and smaller saline level the treatment without biostimulant, B1 and B2, respectively. Already TDM presented reductions more just accentuated in the inexistence of the vegetable regulator, equivalent to $99 \%$ between 0.3 and $5.3 \mathrm{dS} \mathrm{m}^{-1}$, on the other hand, the use of the biostimulants provided increment of $16 \%$ (B1) and $52 \%$ (B2) until the conductivity of $2.3 \mathrm{dS} \mathrm{m}^{-1}$. Possibly, the tenor of water of the plant decreased, in function of the addition of salts in the irrigation water, causing these declines in MFT, however, the use of these biostimulants, mainly the B2 provided increase in MST, that is interlinked to the accumulation of an increase of the plant.

In other words, that effect is due the presence of salts in the solution of the substrate, doing with that increase the retention forces for osmotic effect, and therefore the magnitude of the problem of shortage of water, with that the increase of the osmotic pressure caused by the excess of soluble salts, it can reach a level in that the plants won't 
have forces of enough suction to overcome that osmotic pressure and, in consequence the plant won't absorb water (Gheyi, Dias, Lacerda, \& Gomes Filho, 2016).

Table 3. Mass dries aerial part (MDAP), mass of the root dries (MRD), total fresh mass (TFM) and total dry mass (TDM) in the initial growth of yellow passion fruit plant under saline levels and without and with application of biostimulants. UFCG, Pombal, 2018

\begin{tabular}{|c|c|c|c|c|c|c|}
\hline & \multicolumn{3}{|c|}{ FMAP } & \multicolumn{3}{|c|}{ MRF } \\
\hline & SEM & B1 & B2 & SEM & B1 & B2 \\
\hline S1 & $0.08 \mathrm{Ac}$ & $0.14 \mathrm{Ab}$ & $0.11 \mathrm{Aa}$ & $0.47 \mathrm{Aa}$ & $0.11 \mathrm{ABb}$ & $0.12 \mathrm{Cb}$ \\
\hline $\mathrm{S} 2$ & $0.09 \mathrm{Ab}$ & $0.14 \mathrm{Aa}$ & $0.10 \mathrm{ABb}$ & $0.04 \mathrm{Bc}$ & $0.14 \mathrm{Ab}$ & $0.24 \mathrm{Aa}$ \\
\hline $\mathrm{S} 3$ & $0.03 \mathrm{Bb}$ & $0.08 \mathrm{Ba}$ & $0.09 \mathrm{ABa}$ & $0.05 \mathrm{Bc}$ & $0.11 \mathrm{ABb}$ & $0.16 \mathrm{Ba}$ \\
\hline S4 & $0.03 \mathrm{Bb}$ & $0.06 \mathrm{Ba}$ & $0.08 \mathrm{Ba}$ & $0.4 \mathrm{Ba}$ & $0.08 \mathrm{Bb}$ & $0.11 \mathrm{Cb}$ \\
\hline \multirow[t]{3}{*}{ S5 } & $0.03 \mathrm{Bb}$ & $0.06 \mathrm{Ba}$ & $0.09 \mathrm{ABa}$ & $0.02 \mathrm{Bb}$ & $0.08 \mathrm{Ba}$ & $0.10 \mathrm{Ca}$ \\
\hline & \multicolumn{3}{|c|}{ TFM } & \multicolumn{3}{|c|}{ TDM } \\
\hline & SEM & B1 & B2 & SEM & B1 & B2 \\
\hline S1 & $0.55 \mathrm{Ac}$ & $1.37 \mathrm{Ab}$ & $2.09 \mathrm{Aa}$ & $0.33 \mathrm{Aa}$ & $0.25 \mathrm{ABb}$ & $0.23 \mathrm{Bb}$ \\
\hline $\mathrm{S} 2$ & $0.39 \mathrm{Bc}$ & $0.89 \mathrm{Bb}$ & $1.53 \mathrm{Ba}$ & $0.14 \mathrm{BCb}$ & $0.29 \mathrm{Aa}$ & $0.35 \mathrm{Aa}$ \\
\hline $\mathrm{S} 3$ & $0.37 \mathrm{Bc}$ & $0.72 \mathrm{Cb}$ & $1.49 \mathrm{Ba}$ & $0.08 \mathrm{Cb}$ & $0.20 \mathrm{BCa}$ & $0.25 \mathrm{Ba}$ \\
\hline S4 & $0.35 \mathrm{Bc}$ & $0.90 \mathrm{Bb}$ & $1.14 \mathrm{Ca}$ & $0.19 \mathrm{Ba}$ & $0.14 \mathrm{Ca}$ & $0.19 \mathrm{Ba}$ \\
\hline S5 & $0.24 \mathrm{Cc}$ & $0.76 \mathrm{Cb}$ & $1.12 \mathrm{Ca}$ & $0.05 \mathrm{Cb}$ & $0.14 \mathrm{Ca}$ & $0.19 \mathrm{Ba}$ \\
\hline
\end{tabular}

Note. Saline levels (S1: 0.3; S2: 2.3; S3: 3.3; S4: 4.3 and S5: $5.3 \mathrm{dS} \mathrm{m}^{-1}$ ); Biostimulants (SEM: without biostimulant application; B1: Acadian and B2: Crop Set).

*Following averages for the same small letter in the line and capital letter in the column don't differ statistically amongst themselves for the test of Tukey to $5 \%$ of probability.

The effect of the saline stress and biostimulants was also observed in the percentile of biomass (PB), the seedlings absentees of the application of the biostimulant were affected drastically for the increment of salts in the irrigation water, reduction is of equivalent to $62.71 \%$ of $\mathrm{PB}$ of $0.3 \mathrm{dS} \mathrm{m}^{-1}$ for $5.3 \mathrm{dS} \mathrm{m}^{-1}$, however, the use of the vegetable regulators provided increment $77 \%$ (B1) and $108 \%$ (B2) in PB up to $2.3 \mathrm{dS} \mathrm{m}^{-1}$, refusing starting from this saline concentration, in both biostimulants (Table 4).

When analyzing the index of tolerance the salinity (IT), it was observed that the saline levels of the water interfered negatively in the accumulation of vegetable biomass of the passion fruit plant plants. The smallest index was verified in the seedlings that were not treated with biostimulant with $44 \%$ of IT in the level saline 5.3 $\mathrm{dS} \mathrm{m} \mathrm{m}^{-1}$, while the application through foliating of biostimulants was promising with $80 \%$ of IT up to $3.3 \mathrm{dS} \mathrm{m}^{-1}$, in both treatments (B1 and B2), and the bioestimulant B2 was statistically superior to the $4.3 \mathrm{dS} \mathrm{m}^{-1}$, in other words, it demonstrated larger attenuating action in relation to the treatment B1 (Table 4).

According to Taiz, Zeiger, Moller, and Murphy (2017) the saline stress can provoke nutritional and physiologic unbalance with direct influence in the conversion of carbon assimilated by the plants and promoting reductions in the growth and in the accumulation of biomass of the cultures. The use of bioregulators can reduce these effects, as verified by the biostimulant B2, and it is needed more studies to prove the effect of this biostimulant in other concentrations in the culture of the passion fruit plant submitted to abiotic stress conditions (salinity of the irrigation water). 
Table 4. Percentile of Biomass (PB) and index of tolerance the salinity (IT) in the initial growth of the yellow passion fruit plant under saline levels and without and with application of biostimulants. UFCG, Pombal, 2018

\begin{tabular}{|c|c|c|c|c|c|c|}
\hline & \multicolumn{3}{|c|}{ PB (\%) } & \multicolumn{3}{|c|}{ IT (\%) } \\
\hline & SEM & B1 & B2 & SEM & B1 & B2 \\
\hline S1 & $60.56 \mathrm{Aa}$ & $18.41 \mathrm{Cb}$ & $11.21 \mathrm{Cc}$ & $100.00 \mathrm{Aa}$ & $100.00 \mathrm{Aa}$ & $100.00 \mathrm{Aa}$ \\
\hline $\mathrm{S} 2$ & $36.18 \mathrm{Ca}$ & $32.72 \mathrm{Aa}$ & $23.18 \mathrm{Ab}$ & $72.06 \mathrm{Bb}$ & $85.03 \mathrm{Ba}$ & $86.42 \mathrm{Ba}$ \\
\hline $\mathrm{S} 3$ & $25.07 \mathrm{Da}$ & $27.19 \mathrm{Ba}$ & $17.04 \mathrm{Bb}$ & $63.75 \mathrm{Cb}$ & $79.50 \mathrm{Ba}$ & $83.99 \mathrm{Ba}$ \\
\hline $\mathrm{S} 4$ & $52.22 \mathrm{Ba}$ & $15.43 \mathrm{Cb}$ & $16.65 \mathrm{Bb}$ & $55.83 \mathrm{Dc}$ & $48.09 \mathrm{Cb}$ & $64.38 \mathrm{Ca}$ \\
\hline S5 & $22.58 \mathrm{Da}$ & 19.29 Cab & $16.90 \mathrm{Ba}$ & $44.00 \mathrm{~Eb}$ & $46.39 \mathrm{Cb}$ & $53.33 \mathrm{Da}$ \\
\hline
\end{tabular}

Note. Salinity levels (S1: 0.3; S2: 2.3; S3: 3.3; S4: 4.3 and S5: $5.3 \mathrm{dS} \mathrm{m}^{-1}$ ); Biostimulants (SEM: without biostimulant application; B1: Acadian and B2: Crop Set).

*Following averages for the same small letter in the line and capital letter in the column don't differ statistically amongst themselves for the test of Tukey to $5 \%$ of probability.

\section{Conclusions}

The use of vegetable biostimulants increases the initial growth of the yellow passion fruit plant.

The salinity in the irrigation water attacks the growth, however, use of the biostimulant Crop Set lessens the harmful effect in passion fruit seedlings.

\section{References}

Araújo, E. B. G., Sá, F. V. S., Oliveira, F. A., Souto, L. S., Paiva, E. P., Silva, M. K. N., ... Brito, M. E. B. (2016). Crescimento inicial e tolerância de cultivares de meloeiro à salinidade da água. Revista Ambiente \& Água, 11(2), 463-471. https://doi.org/10.4136/ambi-agua.1726

Batista-Sánchez, D., Amador, B. M., Garibay, A. N., Meléndez, L. A., Diéguez, E. T., Montiel, L. H., \& Silvera, C. M. O. (2017). Mitigación de $\mathrm{NaCl}$ por efecto de un bioestimulante en la germinación de Ocimum basilicum L. Terra Latino Americana, 35(4), 309-320. https://doi.org/10.28940/terra.v35i4.317

Bezerra, J. D., Pereira, W. E., Silva, J. M., \& Raposo, R. W. C. (2016). Crescimento de dois genótipos de maracujazeiro-amarelo sob condições de salinidade. Revista Ceres, 63(4), 502-508. https://doi.org/ 10.1590/0034-737X201663040010

Coelho, M. A., \& Soncin, N. B. (1982). Geografia do Brasil. São Paulo, Moderna.

Emon, R. M., Gregorio, G. B., Nevame, A. Y. M., Islam, M. M., Islam, M. R., \& Ye-Yang, F. (2015) Morpho-Genetic Screening of the Promising Rice Genotypes under Salinity Stress. Journal of Agricultural Science, 7(5), 94-111. https://doi.org/10.5539/jas.v7n5p94

Ferraz, R. A., Souza, J. M. A., Santos, A. M. F., Gonçalves, B. H. L., Reis, L. L., \& Leonel, S. (2014). Efeitos de bioestimulante na emergência de plântulas de maracujazeiro 'roxinho do kênia'. Bioscience Jornal, 30(6), 1787-1792.

Ferreira, D. F. (2014) Sisvar: A Guide for Its Bootstrap Procedures in Multiple Comparisons. Ciência e Agrotecnologia, 38(2), 109-112. https://doi.org/10.1590/S1413-70542014000200001

Francisco, P. R. M., \& Santos, D. (2017). Climatologia do Estado da Paraíba. Campina Grande, EDUFCG.

Freire, J. L. O., Dias, T. J., Cavalcante, L. F., Fernandes, P. D., \& Neto, A. J. L. (2014). Rendimento quântico e trocas gasosas em maracujazeiro amarelo sobsalinidade hídrica, biofertilização e cobertura morta. Revista Ciência Agronômica, 45(1), 82-91. https://doi.org/10.1590/S1806-66902014000100011

Gheyi, H. R., Dias, N. S., Lacerda, C. F., \& Gomes Filho, E. (2016). Manejo da salinidade na agricultura: Estudos básicos e aplicados (2nd ed.). Fortaleza, INCTSal.

Nascimento, E. S., Cavalcante, L. F., Gondim, S. C., Souza, J. T. A., Bezerra, F. T. C., \& Bezerra, M. A. F. (2017). Formação de mudas de maracujazeiro amarelo irrigadas com águas salinas e biofertilizantes de esterco bovino. Revista Agropecuária Técnica, 38(1), 1-8. https://doi.org/10.25066/agrotec.v38i1.28090

Oliveira, F. A., Guedes, R. A. A., Gomes, L. P., Bezerra, F. M. S., \& Oliveira, M. K. T. (2015). Interação entre salinidade e bioestimulante no crescimento inicial de pinhão-manso. Revista Brasileira de Engenharia Agricola e Ambiental, 19(3), 204-210. https://doi.org/10.1590/1807-1929/agriambi.v19n3p204-210 
Oliveira, F. A., Medeiros, J. F., Cunha, R. C., Souza, M. W. L., \& Lima, L. A. (2016). Uso de bioestimulante como agente amenizador do estresse salino na cultura do milho pipoca. Revista Ciência Agronômica, 47(2), 307-315.

Oliveira, F. A., Oliveira, M. K. T., Lima, L. A., Alves, R. C., Régis, L. R. L., \& Santos, S. T. (2017). Salt stress and plant bioregulators in cowpea crop. Irriga, 22(2), 314-329. https://doi.org/10.15809/irriga.2017 v22n2p314-329

Ramos, A. R. P., Amaro, A. C. E., Macedo, A. C., Souza, E. R., Rodrigues, J. D., \& Ono, E. O. (2015). Acúmulo de carboidratos no desenvolvimento de tomateiro tratado com produtos químicos. Semina: Ciências Agrárias, 36(2), 705-718. https://doi.org/10.5433/1679-0359.2015v36n2p705

Rhoades, J. D., Kandiah, A., \& Mashali, A. M. (2000). Uso de águas salinas para produção agrícola. Campina Grande, UFPB.

Santos, V. M., Melo, A. V., Cardoso, D. P., Gonçalves, A. H., Varanda, M. A. F., \& Taubinger, M. (2013). Uso de bioestimulantes no crescimento de plantas de Zea mays L. Revista Brasileira de Milho e Sorgo, 12(3), 307-318. https://doi.org/10.18512/1980-6477/rbms.v12n3p307-318

Silva, M. J. R., Bolfarini, A. C. B., Rodrigues, L. F. O. S., Ono, E. O., \& Rodrigues, J. D. (2014). Formação de mudas de melancia em função de diferentes concentrações e formas de aplicação de mistura de reguladores vegetais. Scientia Plena, 10(10), 1-9.

Souza Neta, M. L., Oliveira, F. A., Torres, S. B., Souza, A. A. T., Silva, D. D. A., \& Santos, S. T. (2018). Gherkin cultivation in saline medium using seeds treated with a biostimulant. Acta Scientiarum. Agronomy, 40, 1-10. https://doi.org/10.4025/actasciagron.v40i1.35216

Taiz, L., Zeiger, E., Moller, I. M., \& Murphy, A. (2017). Fisiologia e Desenvolvimento Vegetal (6th ed.). Porto Alegre, Artmed.

Zacharias, A. O., Zacaroni, A. B., Borges, A. L., Costa, A. M., \& Vaz, A. P. A. (2016). Maracujá. Brasília, Embrapa.

\section{Copyrights}

Copyright for this article is retained by the author (s), with first publication rights granted to the journal.

This is an open-access article distributed under the terms and conditions of the Creative Commons Attribution license (http://creativecommons.org/licenses/by/4.0/). 